I artikkelen Mer til skade enn til gagn - hvor mye skal pasientene vite? - publisert i Tidsskriftet nr. 3/2017 - problematiserte S. Olsen og medarbeidere forholdet mellom informert samtykke og hensynet til den enkelte og samfunnet i forskningsstudier. Etter deres mening kunne «velmente pålegg for å ivareta personvernet ha motsatt effekt og påvirke deltagernes velferd negativt». Det har utløst debatt.

\section{Re: Mer til skade enn til gagn - hvor mye skal pasientene vite?}

Informasjonsbrev om forskningsprosjekter kan gi opphav til misforståelser og engstelse, skriver Sofia Olsen og medarbeidere, og stiller dermed «spørsmål ved behovet for samtykke eller reservasjonsrett ved studier uten intervensjoner».

Et gammelt ordtak sier at «det man ikke vet har man ikke vondt av». Helsinki-deklarasjonen om etiske prinsipper for medisinsk forskning som omfatter mennesker sier noe annet, og det samme gjør helseforskningsloven. Her er det et viktig prinsipp at pasienter skal informeres om forskning på deres helseopplysninger og få anledning til å reservere seg fra å delta. Dette prinsippet følger av forskningsdeltakernes rett til selvbestemmelse. Helsinki-deklarasjonen sier også at «Ingen nasjonale eller internasjonale etiske, juridiske eller regulatoriske krav skal begrense eller sette ut av kraft noen av de beskyttelsesmekanismene for forskningsdeltakere som er nedfelt i denne deklarasjonen.»

Mennesker er ulike og har ulike behov. For noen kan informasjon føre til misforståelser og engstelse. Løsningen på dette er ikke å la være å informere, men å informere på en bedre måte. Det er forskerens ansvar å gjøre dette og sørge for å være tilgjengelig slik at forskningsdeltagere kan få svar på eventuelle spørsmål de måtte ha.

\section{Frederik Kragerud Goplen}

frederik.goplen@helse-bergen.no

Frederik Kragerud Goplen (f. 1968) er overlege ved Øre-nese-hals-avdelingen, Haukeland universitetssykehus.

Ingen oppgitte interessekonflikter.

\section{Re: Mer til skade enn til gagn - hvor mye skal pasientene vite?}

I likhet med Frederik Kragerud Goplen mener jeg det er viktig å gi god informasjon på riktig måte for å unngå misforståelser og engstelse. Samtidig måtte jeg spørre meg selv: Hva var det egentlig kvinnen og de andre reagerte på når de ble tilskrevet? Kunne det like godt være det at de ikke var klar over at de var oppført i Kreftregisteret de reagerte på? Hvem er det egentlig som er registrert i Kreftregisteret? Er jeg også registrert i Kreftregisteret, selv om jeg aldri har fått påvist kreft? Etter å ha vært inne på Kreftregisterets hjemmesider kom jeg faktisk frem til at: - Ja, mest sannsynlig er jeg også oppført i Kreftregisteret, på grunn av en endring i helseregisterloven i 2014. Denne endringen innebærer at opplysninger om personer som blir undersøkt for kreft via et screeningprogram og som registreres med normale funn, kan lagres i Kreftregisteret, med mindre de aktivt motsetter seg dette. Ettersom to av de eksisterende tre screeningprogrammene er forbeholdt kvinner, vil det også være mange flere kvinner oppført i Kreftregisteret til tross for at de verken har kreft eller forstadier til kreft. Videre vil jeg tro at de fleste, meg selv inkludert inntil nylig, ikke har tenkt over at deres personopplysninger og normale prøveresultater er tilgjengelig for forskning. Dermed er det særdeles viktig at forskere tar hensyn til dette når de skal tilskrive noen i forbindelse med et forskningsprosjekt hvor man skal undersøke risiko for kreft. Kanskje burde de som ikke har noen kreftdiagnose og som skal inngå i en kontrollgruppe få et eget tilpasset informasjonsbrev?

For øvrig er det noen vesentlige opplysninger, som er med på å forklare REKs behandling av studien, som er utelatt i innlegget til
Olsen og medforfattere. I innlegget fremstilles det som at forskerne av REK ble pålagt å tilskrive 50000 personer som er oppført i Kreftregisteret. Ut fra klagesaksvedtaket til Den nasjonale forskningsetiske komité for medisin og helsefag (NEM) fremgår det imidlertid at det kun var krav om å tilskrive 417 gjenlevende av 800 med påvist tarmkreft og 800 kontroller med adenom, men uten kreft. Jeg antar at det er disse personene det $\mathrm{i}$ innleggets første avsnitt refereres til som de «noen pasienter» der det skal gjennomgås pasientjournal for å supplere registerdata. For øvrig nevnes det ikke i innlegget i Tidsskriftet at man i tillegg skulle utføre molekylære analyser av DNA-, RNA- og proteinbaserte markører på vevsprøver fra disse pasientene. Vevsprøvene og opplysningene i pasientjournal er innhentet i helsetjenesten for diagnostikk og behandling av den enkelte pasient. Derfor foreligger det ikke noe informert samtykke for bruk av biologisk materiale og journalopplysninger til bruk i forskning her. Bruk av biologisk materiale $\mathrm{i}$ forskning er strengere regulert enn bruk av kun helseopplysninger. Selv om hovedregelen i medisinsk og helsefaglig forskning er informert samtykke har REK anledning til i å innvilge fritak fra samtykkekravet. Men for å kunne gjøre dette ved bruk av biologisk materiale innhentet $\mathrm{i}$ behandlingsøyemed til forskning må deltagerne på forhånd ha blitt informert om dette og ha fått mulighet til å reservere seg jf. helseforskningsloven $\S 28$.

\section{Linda T. Roten}

linda.tommerdal@ntnu.no

Linda T. Roten (f. 1979) er forsker ved Institutt for laboratoriemedisin, barne- og kvinnesykdommer (LBK) og rådgiver hos Regional komité for medisinsk og helsefaglig forskningsetikk (REK) Midt-Norge ved Norges teknisk-naturvitenskapelige universitet.

Ingen oppgitte interessekonflikter.

\section{Re: Mer til skade enn til gagn - hvor mye skal pasientene vite?}

Sofia Olsen og medarbeidere drøftet nylig spørsmålet om samtykke ved registerststudier uten intervensjoner. Eksempelet var en studie om risiko for tarmkreft hos personer som tidligere har fått fjernet adenomer i tykktarmen. Informasjonsbrevet førte til en del engstelse. Problemet vil løse seg ved bedre informasjon mener Frederik Kragerud Goplen i sitt tilsvar. Han legger ansvaret på forskerne, men det er for enkelt. Vi må være realistiske nok til å innse at tusenvis av brev om adenomer vil skape en del bekymring, uansett brevets formuleringer og forskerens tilgjengelighet på telefon eller mail. Adenomet kan for eksempel være glemt eller fortrengt. Fasiten på hvordan man best ivaretar pasienters velferd og integritet i denne saken er ikke åpenbar. Et viktig prinsipp i Helsinkideklarasjonen er å informere om forskning på pasienters helseopplysninger, men i Norge blir vi jo forsket på alle sammen. Det starter allerede ved fødselen med Medisinsk fødselsregister som skal «drive, fremme og gi grunnlag for forskning...». Det fortsetter med Nasjonalt vaksinasjonsregister, Reseptregisteret, Kreftregisteret, Hjerte- og karregisteret og ytterligere 12 sentrale helseregistre før det hele avsluttes med Dødsårsaksregisteret - uten noen reservasjonsrett. Sofia Olsen og medarbeidere reiser etter min mening en viktig debatt som jeg håper de etiske komiteer vil gå inn i. Hvordan kan man best kan forvalte samtykkekravet $\mathrm{i}$ registerstudier uten noen form for intervensjon. Hvordan unngå at det beste blir det godes fiende i balansen om velferd og integritet?

\section{Kjetil Retterstøl}

kjetil.retterstol@medisin.uio.no

Kjetil Retterstøl (f. 1962) professor ved Universitetet i Oslo og overlege ved Lipidklinikken, Oslo universitetssykehus.

Ingen oppgitte interessekonflikter. 